\title{
Bulwark of Liberty or Backward Savagery? Dispute Between Rousseau and the Polish Enlightenment Thinkers Over Eastern Europe
}

\begin{abstract}
Jan Květina
University of Hradec Králové

This study aims to question the traditional interpretation of the Enlightenment discourse, which rests upon the assumption that Eastern Europeans were considered as uneducated savages (an image created by Western European elites) that need to be developed according to the principles of Western civilization. Such a view might be deemed incomplete and thus misleading. Of course, there have always been many "Western progressive thinkers" who promoted the idea of westernization of the East, as well as there have been plenty of Eastern Enlightenment intellectuals holding onto Western ideals as a means of salvation from backwardness. However, one should admit that the original Eastern structures of state and society represented an inspiring alternative that enabled some theoreticians to get a different viewpoint; as obvious in the Polish case. Taking the uniqueness of their 18th century political system into account, one is able to acknowledge the importance of the Polish internal debate that tried to answer whether a republican spirit of the state was something that should have been preserved or completely rejected. In terms of the East-Western dichotomical point of view however, it is essential that this contradiction between republic as "bulwark of freedom" and "backward barbarism" did not only represent a local issue, but also piqued Western curiosity, especially Rousseau's one. Hence, it is fully legitimate to analyse his approach towards this Eastern European country and his conclusions that contradicted both the Western as well as the Polish common convictions that the region was something undesirable. Thus, the main purpose of this paper is to analyse and explain the tensions between Rousseau and Polish Enlightenment thinkers such as M. Wielhorski or S. Leszczyński and, by clarifying them, to reveal a deeper ambiguity of the Enlightenment discourse concerning the interpretation of Eastern Europe as well as human nature.
\end{abstract}

Keywords: Enlightenment, Poland, J. J. Rousseau, S. Leszczyński, M. Wielhorski

\section{Introduction: Roots of Blurred Borders Between East and West}

Although there has never been any precise delimitation of Western and Eastern Europe which would have defined the borders between both these regions exactly and once and for all ${ }^{1}$, one must admit that there have been many stereotypes trying to prove that something like Western or Eastern affinity should be considered as a much more important issue than just the question of geographical location. Moreover, it may be ventured to

Jan Květina, Ph.D., Dr., researcher at University of Hradec Králové, assistant professor at Metropolitan University in Prague and lecturer at Charles University in Prague and Gymnázium J. K. Tyla in Hradec Králové, Czech Republic; main research fields: History of Ideas, Polish Political Thought, Republicanism, Nationalism. 
state that many times the division between East and West has become a symbol of the difference between sameness and otherness, the symbol demarcating the line between the citizens of the same spirit and those who inhabit the foreign and unknown lands of hic sunt leones. This means that both East and West could serve as the fundamental principle for the image of enemy, as Carl Schmitt puts it in his understanding of the political space. $^{2}$ However, even if many of those stereotypes and images are still present and influential in contemporary Europe, it is possible to claim that particularly due to the postmodern paradigm shift the main principles of those stereotypes could be now interpreted as mere instrumental constructions supporting some particular higher truths, values, and interests.

This is especially obvious if one analyses some of those most commemorated and influential theories concerning the distinction between European East and West in the 20th century, both in political theory or politics itself. When Winston Churchill uttered his self-fulfilling prophecy about the fate of "all those famous and ancient capitals of Central and Eastern Europe" (Muller 1999, 8) ${ }^{3}$, he was not just describing reality, nor even constructing it, but he was struggling to establish fundamentally new foreign and global policy on the basis of this Eastern-Western dichotomy. When Immanuel Wallerstein introduces his renowned World-System Theory, he finds the roots of the modern capitalist world system in an unequal development of different European parts from the 16th century leading to those underdeveloped, decentralized, and agricultural regions like Poland in Eastern Europe becoming peripheries, i.e., the source of raw materials and cheap labour that could be exploited by the states of the core. ${ }^{4}$ Again in this case, the line between West and East in Europe is not an end in itself; one can even say that the borders in Wallerstein's theory are blurred and thus ambiguous, because it's hard to define where the core ends and periphery or semi-periphery begins. However, what really matters is not the borderline or the difference between Western and Eastern way of economic life, but the Dependency theory that can be deduced from it. And last but not least, when the concept of Central Europe has been reinvented by the "Eastern" European intellectuals like Milan Kundera, Jenő Szücs, or Czesław Miłosz ${ }^{5}$ in the last phase of Cold War, their interpretation of Central Europe as multicultural mental space which has always belonged to the West by its identity, but was politically captured by the East reflected more a wishful-thinking and effort to pique curiosity of Western European countries than objective categorization of current Eastern-Western differences.

Nonetheless, even if we accept the constructivist notion about the artificial, discursive, and purpose-built essence of Eastern-Western Europe dichotomy, one is urged to define its starting point, which means to find a symbolic moment, when the alternative and competing delimitations of European space were overwhelmed by the single East-West distinction. As many classics of European historiography prove, this distinction must be perceived as a result of modern industrial era, because from the antiquity till the Renaissance the prevailing spatial distinction was based on the tension between North and South in terms of changing contrast between civilisation and barbarism ${ }^{6}$ and it was not before the Congress of Vienna when the categories of East and West were basically introduced in the political discourse concerning European spheres of interest. ${ }^{7}$ Thus, it is not so surprising that all premodern distinctions between East and West like the different level of Roman heritage, religious schism, the impact of Asian influences, birth of bourgeoisie etc. are commonly described as pre-symptoms or rather causes that could have been interpreted retrospectively, but are not considered to be moments of ultimate discursive constitution of Eastern Europe as such. I suppose, though, that such a moment is frequently sought and usually linked with ideas of Enlightenment, as the concept of Eastern Europeans as backward savages who need to be civilised is strongly dependent on the enlightened principles of human 
reasonable evolution and its universal form that can be deduced from the developmental stages of Western societies. Of course, one is able to find many features during the late 18th century proving that the interpretation of East-West dichotomy of that time in terms of superiority and submission is the right one. As Wandycz puts it, this era gave a birth to the feeling of cultural hierarchy, because most of Western Europeans "mingled condescension with ignorance" towards the nations of Eastern Europe and vice versa, "Poles, Hungarians and Czechs often looked up to the West...with a mixture of adoration and envy" (Wandycz 2005, 4). ${ }^{8}$ This traditional interpretation therefore assumes that contemporaries of the Enlightenment identified all the progressive tendencies with Western Europe, which in addition served as inspiration or even imitation, whereas undesirable and pernicious features were condemned as "Eastern traits."

\section{Rousseau and Poland: Two Different Debates}

Taking all these stereotypes into account, this paper does not try to reject the traditional interpretation of East-West dichotomy as an intellectual product of the Enlightenment as a whole, instead, it struggles to doubt two assumptions that have been accepted nearly unambiguously so far and that have been mentioned above:

(1) Common belief about Eastern Europe as space that must be transformed according to Western patterns for the sake of progress of its inhabitants should not be treated as a conviction shared by all the Western intellectual elites of the Enlightenment, because there were influential exceptions. Those exceptions, on the contrary, understood Eastern Europe as a pure and incorrupt world that had been already lost in the West and thus they argued that it is just the set of those frequently denunciated "Eastern traits" that cherish the hope for universal salvation of humanity. It must be noted that the chief representative of the aforementioned extraordinary Western European belief may be considered J. J. Rousseau, when his Considerations on the Government of Poland can be read not only as an instrumental programme of needed reforms, but as a part of his whole political theory. The main way to weaken the traditional interpretation of Enlightened East-West dichotomy is therefore to prove that Rousseau's involvement into Polish business relates to his general concept of human and society and thus calls for universal claims.

(2) The second traditional assumption that must be revised concerns the standard classification of Eastern European's attitudes towards technological and cultural superiority of the West from the Enlightenment onwards. When Wandycz describes those attitudes as a mixture of adoration and envy, it is necessary to add that many authors - including Wandycz himself-identify these reactions with the existence of two antagonist and prevalent approaches in Eastern Europe of that time which is clearly visible in the case of tension between zapadniks and slavophiles in Russia or Enlighteners and Sarmats in Poland. ${ }^{9}$ The essence of this distinction is obvious, because Eastern European citizens (or rather inhabitants) could either accept their subordinated position in comparison with the West and thus call for westernization or reject the idea itself by glorification of their national history and uniqueness. However, there is a great danger of excessive simplification regarding this antagonism, because it underestimated the presence of various political as well as philosophical positions that did not fit into a mere response to the question of cultural superiority or submission, because their adherents denied either to adore or diabolise the Western values. Such position can be found particularly in Polish political discourse, where a peculiar republican movement emerged in the clash between supporters of Western Enlightenment and traditional Sarmatism. The leading figures of this position who took part in the legal uprising of Bar Confederation promoted the ideals of domestic republicanism lying in modern individualist concept of a man (which contradicted the ideals of Sarmats) as well as in an effort to establish 
revived Polish society on the basis of old Polish republic (which contradicted the ideals of Enlighteners). This means that the proportion between Western inspiration and Eastern tradition was uniquely and harmonically balanced in this case. $^{10}$

Nonetheless, what is really intriguing about both these objections to the traditional interpretation of the Enlightenment concept of Eastern Europe is the fact that there is a connecting link between them represented by the personality or even more by ideas of J. J. Rousseau. It has been already mentioned that Rousseau's Considerations should be read as a general and paramount revolt against the intellectual and ideological rule of Western culture over Eastern European way of life. However, one should not ignore the fact that Rousseau's reflections and conclusions played a particular role even in the establishment of the aforementioned discourse of Polish radical republicans, whose main adherents were fully acquainted with works of Rousseau and wrote their own proposals partly as a reaction to those of the French philosopher.

This is especially true with regard to the case of Michał Wielhorski, the Polish nobleman and envoy of the Bar Confederation in Paris, whose fate basically mirrors the role of Rousseau in Polish matters. As it is commonly known, it was him who addressed famous French intellectuals including Rousseau with a request to write down the list of necessary reforms for saving the Polish state. As Rousseau admits in his Considerations he is "to obey Count Wielhorski and give earnest of his zeal for his country", and he knows "no one better qualified to elaborate such a plan than Count Wielhorski" (Rousseau 1985, 1-2). ${ }^{11}$ Nevertheless, despite the fact that Rousseau appraised his knowledge, conclusions of Rousseau differed somehow significantly from the original concepts of Wielhorski, which is obvious when one takes into consideration his own political theory that Wielhorski presented in his work O przywróceniu dawnego rzqdu few years later. Thus, it is apparent that Rousseau's ideas not only revolted against acknowledged image of Eastern Europe of that time, but also fundamentally influenced the Polish political thought at the same time.

This influence should not be underestimated, notably if one realizes that the cooperation with Wielhorski was not the only involvement of Rousseau in Polish political or rather philosophical space. That is why I claim we can distinguish two distinct debates between Rousseau and the representatives of Polish Enlightenment, debates that were led with different partners about different subjects, but still had something in common. The first debate took place in the early 50s of the 18th century and was conducted between Rousseau and Polish nobleman and nominal Polish-Lithuanian king Stanisław Leszczyński ${ }^{12}$ about human nature and praiseworthy virtues for human life. As the second debate we can label the aforementioned mutual exchange of views between Rousseau and Wielhorski that started as a written introductory lecture about Polish constitution for Rousseau, proceeded with Rousseau's Considerations and ended with Wielhorski's masterpiece that could be labelled as the summary of Polish radical republicanism as well as the response to Rousseau. The very important fact that both these debates actually did take place between the players who acknowledged their counterparts and reflected on their comments prevents us from being accused of creating mythologies, as Skinner warns in the case of comparing ideas from different contexts. ${ }^{13}$ Moreover, the legitimacy of such comparison is even supported by the recurrent issues in both debates, i.e., the different Western and Eastern perspectives about reasonable principles for man and society; something still evident despite the first debate focusing more on philosophical and the second one more on political matters.

\section{First Debate: Against Individualism Concerning Human Nature}

If we start with the first case, it should be noted that "Rousseau-Leszczyński debate" was led as an 
argument about human nature and purpose of knowledge when the Polish formal king responded to some conclusions from the Discourse on the Arts and Science ${ }^{14}$ and Rousseau later rejected Leszczyński's objections with his own answer. ${ }^{15}$ The antagonistic nature of their polemic is highly undeniable although Rousseau explicitly appreciated the effort of his opponent and emphasized his respect to him $^{16}$, because if one focuses one's attention from formal to substantial things, one must notice that both the authors contradict completely each other.

The most serious argument raised by Leszczyński against Discourses is probably his rejection of interdependency between the rise of sciences and fine arts on one hand and the existence of abundance, idleness and comfort in human society on the other hand. He denies this misled causality between wealth and knowledge using an example of philosophers who have always been able to deal with science not because of luxury but with the lack of it: "how many Philosophers reduced to beggary, wrapped in their own virtue and ignored in their solitude account for every Plato who is wealthy and every Aristippus who is respected at Court?" (Leszczyński 2000, 641) ${ }^{17}$ Moreover, he rejects not only the aforementioned causality, but particularly Rousseau's conclusion that sciences are dangerous as they arise from laziness, further support it, and thus lead to the decay of morality and social effeminacy. ${ }^{18}$ Leszczyński tries to refute this thesis by highlighting all those great philosophers and legislators from Egypt, Greece, Rome, or China who did not cause a moral decay but, on the contrary, helped to maintain manners and order. ${ }^{19}$ These arguments are meant to prove the essential true according to Leszczyński- that a man is a rational creature who can be distinguished from other animals just by his reason which enables him to recognize what is right or wrong, to face perceptual tricks of his senses and use science to understand the world properly. Nonetheless, they also reveal the fundamental tension between Rousseau's and Leszczyński's interpretation of the world and social behaviour: the dispute whether society should be treated individually or rather collectively. It is not surprising that the identification of this dispute is somehow crucial for the purpose of this study, as the strictly individualist approach of Leszczyński represents typical standpoint of the Enlightenment that is however advocated by the Eastern philosopher, whereas Rousseau as a product of Western thought urges for the collectivist conception of community and for social solidarity.

Thus when Leszczyński suggests: "the more a society supports science, the better life is lived in it" (Leszczyński 2000, 637) ${ }^{20}$, he does not understand this life as a collective entity reflecting some kind of common good; instead, of it he promotes the ideal of mutual progress of emancipated individuals, which means that the aforementioned better life is a symptom of convergent, not collective good. ${ }^{21}$ In contrast, when Rousseau responses to Leszczyński's complaints, he totally denies his individualist point of view by claiming that it is not the case of particular philosophers or scientists that should be analysed, because what does really matter is depravity and inequality of those societies which are based on a scientific obsession: "the first source of evil is inequality, from inequality arose riches...from riches are born luxury and idleness, from luxury arose the fine Arts and from idleness the Sciences" (Rousseau 1997, 45). ${ }^{22}$

The dispute of both these thinkers over essential nature of society is therefore accompanied by the question about ideal and just social order, in which Leszczyński again promotes the meritocratic principles of fair and desirable inequality that can distinguish those who are able to use their reason properly from those who are not. Rousseau's arguments are, of course, contradictory as he is convinced that "the arts, literature and the sciences...fling garlands of flowers over the chains which weigh them down...necessity raised up thrones; the arts and sciences have made them strong" (Rousseau 1997, 6). ${ }^{23}$ 
While Leszczyński holds up science as a tool and possibility of individual emancipation, Rousseau sees the great danger lying in a threat of losing common interest and preservation of unfree society. Hence he is willing to admit that "science in itself is very good" ${ }^{24}$, but it does not matter in the end, because society is not so well organized to be able to prevent itself from harm: "science, however beautiful, however sublime, is not made for man, that his mind is too limited to make much progress in it, and his heart to full of passions to keep him from putting it to bad use" (Rousseau 1997, 33). ${ }^{25}$

So if Leszczyński reproaches Rousseau for not admitting that virtue and science can exist in mutual harmony, he misses the point, because the question is not whether someone is able to be both virtuous and learned, but that too much knowledge means danger for society as a whole which is evident when he utters that "the cultivation of the Sciences corrupts a nation's morals, this is what I dared to maintain" (Rousseau 1997, $35) .{ }^{26}$ Again, a very important difference between individual and collective understanding of human behaviour appears here.

Moreover, there is a wide gap between Leszczyński and Rousseau concerning inherent attributes of human nature that reflects the dispute whether development of human race should be understood progressively or rather regressively. In this regard, Leszczyński tries to denounce Rousseau's visions of an innocent and good primitive savage as nonsense and myth, when he claims that "to pander constantly to the original simplicity...of social innocence... is nothing more than to draw just an ideal portrayal that one can delude oneself with" (Leszczyński 2000, 639). ${ }^{27}$ It means that according to Leszczyński evil and badness are inherent to human nature without any social influence ${ }^{28}$, which causes that all the people need their reason to improve themselves and to live in accordance with moral rules. Human history is thus treated as a progressive development from chaotic stages towards enlightened future, where desire for knowledge plays a key role, as "the more one knows, the more one feels that he must find out even more" (Leszczyński 2000, 638) ${ }^{29}$ and "the more easily he can make aesthetic, moral and customary judgments" (Golka 2012, 66). ${ }^{30}$ Without reasoning one loses their humanity and can be mistaken for a simple animal, ${ }^{31}$ because to behave morally requires to experience evil and reason is the only way to distinguish vice from virtue; as a botanist can recognize a poisonous plant only by research ${ }^{32}$, so can only an educated man distinguish duty and virtue from crime. The ignorance cannot be virtuous, because only the one who has to choose between good and evil and knowingly struggles for the first is a truly moral person.

Even in this case Rousseau strongly protests, first against the idea that human society should be improved, because he promotes the vision of lost golden age that must be found in times of traditional altruistic solidarity and not in egoist depravity of modern society. Nonetheless, the main attack is led against above mentioned intellectual elitism of Leszczyński who calls for the community of educated individuals who will be able to develop their political virtues thanks to their emancipated reason. Rousseau strictly refutes this idea by the allegory of the Philosopher and the Plowman, where philosopher is someone who seeks eternal wisdom and loses his time by mere thinking, while Plowman is happy just because the sun and rain fertilize his lands ${ }^{33}$ causing that he is ready for proper work without any useless asking.

For this reason the first contact of Rousseau with the Eastern European spirit can be described as the mutual overturn of the relationship between Western civilization and Eastern barbarism. As it has been shown, Leszczyński is the one who asserts the enlightened principles of individualist society and calls for permanent progress based on meritocratic intellectual elitism, whereas Rousseau emphasizes ideals of natural togetherness, traditional intuition, and common sense. 


\section{Second Debate With Wielhorski: Against Depravity of Western Societies}

Similar standpoints can be found even in the second debate between Wielhorski and Rousseau, whose motivation for the involvement into this case remains a little bit mysterious. It must be noted that Rousseau was not well acquainted with Polish society, which he admits by writing that "only the Poles or someone who has made a thorough first-hand study of the Polish nation and its neighbours, can devise good legislation for Poland" (Rousseau 1985, 1) 34 $^{34}$ which was of course not his case. I am thus convinced that to figure out Rousseau's motives and to understand his whole Considerations on Poland it is necessary to explain why his response was so surprising for Polish nobility and to prove that even if his conclusions in this work seem to contradict his whole previous political theory, they can be read as a harmonious complex anyway.

To understand the initial feelings of Polish reformers who were confused with recommendations of Rousseau it is convenient to mention one of the first pieces of advice that the French philosopher provides: "Think twice, brave Poles! Never forget, as you dream of what you wish to gain what you might lose. Correct the abuses of your constitution if you can but do not think poorly of it. It has made you what you are" (Rousseau 1985, 2). ${ }^{35}$

As it has been highlighted, this opening statement is actually shocking not only because it contradicted the radical expectations of Polish clients like Wielhorski, but due to an apparent discrepancy compared to the main principle promoted in Social Contract. This principle is actually the revolutionary one, because Rousseau understands every hierarchic system as unacceptable and illegitimate if it does not meet the test of the supremacy of general will and because he advocates struggle for the liberation of every individual from the chains of society. Considerations on Poland, by contrast, is not a call for revolution at all but, quite the contrary, it could be characterized as an ultraconservative appeal at first sight, as to advocate Polish status quo meant to become a defender of an oppressive system based on aristocracy and serfdom.

So how is then possible to talk about consistent political theory of Rousseau, if he praises equality of all the people and advocates the rule of nobles at the same time? And is it truly inevitable to explain those incoherencies by Rousseau's ideological turn? I do not think so and then I claim there is an inherent connection between The Social Contract and Government of Poland concerning the same concept of society as well as ideal principles of citizenship. In this respect it is necessary to ignore the traditional conviction that the desire for preservation of status quo has to be connected to the conservative way of thinking. Hence, it is crucial to focus more on the passage "Do not think poorly of your constitution, it has made you what you are" than "never forget what you might lose", because it proves that Rousseau again promotes the collectivist or rather holistic concept of society, as he did in the previous debate with Leszczyński.

This is particularly evident when he describes the qualities of Polish society that are viewed as a result of well-established principles of common way of life and not as a consequence of some praiseworthy individual features. Moreover, when Rousseau warns Poles not to change their constitution significantly, it seems that he appreciates only the political form of the Polish state, but one has to take into account that what he really promotes and wants to save is Polish society in general. There is a very interesting fact in this regard that Rousseau works with the concept of a nation as a given fact and natural category. Individuals, politicians, and legislators do not act outside cultural context, because there is a national community "with its tastes, customs and prejudices" (Rousseau 1985, 1) ${ }^{36}$ that Rousseau regards as a plant which is so deeply rooted that there is no possibility to uproot it and plant it in a different field. In other words, if Poles betrayed the national ideals 
which have formed them, they would cease to be Poles, because they would give up the rules that had helped to create and maintain their national community. ${ }^{37}$

I suppose that right now we should let Wielhorski speak for the first time in this debate, because his concept of Polish society can reveal very important differences between his and Rousseau's proposals. It is appropriate to state, though, there were some crucial principles that both Rousseau and Wielhorski were able to agree upon which causes that if when flicking through both their concepts, one can conclude that Wielhorski adopted the original thoughts of Rousseau. This is apparent for example when he upholds the old virtue of Polish ancestors by claiming that what is needed is "return to Poland's old laws - each state has its own founding law or principle, which, if grounded on the law of nature, assures it of its flourishing" (Lukowski 2012, 139; Wielhorski $1775,251,118)^{38}$ or when he gives reasons for maintaining freedom of Poles by referring to ancient traditional relics. ${ }^{39}$ It is undeniable that this principle resembles Rousseau's aforementioned exclamation about old Polish constitution that has made Poles what they are, which means that both Rousseau and Wielhorski admired Polish traditional society and called for its resurrection.

However, it is necessary to show that they both understood Polish society differently, because, in comparison with Rousseau, Wielhorski treats society as a group of individual noblemen who have formed their state for protecting their interests and natural values like freedom and equality. Again, this might seem that Wielhorski shared the same concept of social contract that Rousseau had articulated years before, but, in fact, Wielhorski's contract between individuals is based much more on ideas of John Locke than those of Rousseau. It is intriguing that Wielhorski himself highlights his admiration of Locke when he writes that "people who are born free, equal and independent...cannot be subjected to any power without their own consent" and mentions that this sentence comes from "famous Locke" (Wielhorski 1775, 85). ${ }^{40}$

Contrary to the image of Rousseau, human beings are led by utilitarian motives according to Wielhorski and thus all the cooperation among free people should be seen just as a sum of individual interests and not as pursuit of public good. This utilitarian approach is clearly visible when one compares the visions of Rousseau and Wielhorski concerning rewards and punishments for those citizens who would serve their homeland gallantly or, on the contrary, fail to satisfy its needs. Faithful to his collectivist perspective, Rousseau thinks about symbolic rewards like lifetime public respect for merits or severe penalties like capital punishment if someone traits Poland by disrespecting common good $^{41}$, which really contradicts visions of Wielhorski who promotes financial wages and fines for all elected officials. ${ }^{42}$ That is also the reason why Wielhorski calls for rigorous hierarchy concerning all levels of public services, because personal ambitions to achieve higher positions based on strict meritocracy is the core of healthy republics as they support mutual competition and lead to general rise of motivation:

If motivation is given for an honest and decent magnanimity, then the love of fatherland will be continually incited. Whatever high dignity one attains, there always exists a higher and more venerable one to be desired, thus the senators will aim at becoming commissaries and the commissaries ministers, whereas the ministers will try to fulfil their duties so carefully and seriously as to become worthy of obtaining them for a second or third time, and perhaps even of the crown as a final reward of their virtue, work and good features. (Wielhorski 1775, 320-1) (3) $^{4}$

Moreover, one can identify the tension between collectivist and individualist approach even in the relationship of Wielhorski and Rousseau towards the so called liberum veto, the right of every individual noble deputy to deny discussed agenda by his single disapproval. It is well known that the question whether to abolish this privilege or rather preserve it represented the crucial symbol between the traditional camp of Sarmats who 
considered liberum veto as guarantee of noble freedom and the modern political groups promoting ideas of the Enlightenment that criticized its misuse leading to the state failure. That's why it should not be surprising that although Wielhorski supports individual interests, he is the one who labels this privilege as liberum rumpo and demands its complete abolition, because he does not regard it as a tool for fulfilling those necessary partial concerns but, quite the contrary, as a malignant principle supporting bribery and clientelism and thus threatening individual independence. ${ }^{44}$ Hence, one can understand why Walicki claims that Rousseau was a greater Sarmat ${ }^{45}$ than Wielhorski had ever been, as he strived to preserve Polish traditional system in a much broader way. In the case of liberum veto, for instance, Rousseau criticized his abundance and bad use similarly as Wielhorski, but he was also willing to identify its essence with principles of general will and thus to admit its importance concerning protection of the country, because when majority is false, "it is a great evil for a good citizens to be afraid to speak when they have useful things to say" (Rousseau 1985, 41). ${ }^{46}$

The issue of good citizenship raises the previous question regarding Rousseau's belief that Polish traditional community must be preserved at any cost. There again should be noted that he struggles for salvation of the Polish nation and not necessarily the state. This means that, contrary to Wielhorski who advocated the Polish constitution as a shield of noble interests and values, Rousseau admired virtues of Polish solidarity instead - and even if those were formed and protected by Polish sovereignty, they represented a praiseworthy value as such. This fact is truly evident when Rousseau allows a possibility that Poles will lose their state, but he does not recognize it as an insoluble disaster, because when he advises Poles to "establish the Republic in your hearts" (Rousseau 1985, 10) ${ }^{47}$ it is obvious that for Rousseau it is identity and not a state that really matters. Distinct Polish identity is actually decisive principle of salvation, because states can be captured or even destroyed, but what prevents virtuous community from being ruined is its awareness of difference. As Rousseau utters, it is the "patriotic zeal which no army can possibly breach" the neighbouring states like Russia would swallow Poles, they "shall not be able to digest them" (Rousseau $1985,11)^{49}$

Needless to say, Polish identity is something really valuable as well as unique for Rousseau, but it is useful to highlight that one of the most important parts of this identity is the aforementioned principle of otherness. This means that Rousseau does not struggle so much to define what the Polish nation is; rather, he excludes what the Polish nation is not and should not be, because to be Pole means not being like anyone else, in short to be distinctively different. This comment brings us back to the question of Western and Eastern European borders, because Rousseau establishes an important contrast between both these parts concerning dichotomy of liberty which strongly resembles the concept presented later by Benjamin Constant in his famous essay "The Liberty of the Ancients Compared With That of Moderns." ${ }^{, 50}$ On the basis of this contradiction Rousseau claims that modern European nations are in constant crisis because they have not been able to maintain the legacy of ancient values: "when we read the history of the ancients it seems to us that we have moved into another universe and are surrounded by beings of another species-our Frenchmen, Englishmen, Russians - what are they compared to the Romans or the Greeks?" (Rousseau 1985, 5) ${ }^{51}$

Rousseau is convinced that they are almost nothing, he even denies signifying them according to their nationalities and refers to them just as Europeans, who "all have the same tastes, passions, customs" (Rousseau $1985,11){ }^{52}$ Moreover, he sharply criticised them for hypocrisy, because they blather on about how unselfish they are and how they think about the public good, but in fact they all think only of themselves. This lack of virtue in their national identities is why Rousseau refuses to consider them nations, because "their fatherland is 
any country where there is money to steal and women for them to seduce" (Rousseau 1985, 12). ${ }^{53}$

However, bearing Eastern Europeans in mind, there is one exception to this degeneracy of modern European nations according to Rousseau, and that is the Polish nation. He argues that it is the only one in Europe (and probably also in the world) that has been able to maintain the ancient values and thus revolt against the concept of modern man. This is the reason why Rousseau did not join the Polish reformers in their enthusiasm for changes in Western European style and instead proclaimed that it is necessary to remain Poles. In this regard, Rousseau advocates the desirable principle of otherness again, when he is obsessed with the vision that all citizens must actually see their own republic in every aspect of life. That is why Poles have to wear distinctively Polish clothing and not the French fashion, why they have to play their own national public games, why they should prohibit all foreign celebrations, comedies, operas and write their own Polish ones which would correspond with the principle "Ubi patria, ibi bene" (Rousseau 1985, 14). ${ }^{54}$

On the basis of this rigorous dichotomy between the decadent West that has been already spoiled and the pure Poland that provides a hope for the next generations, it is possible to interpret the crucial difference between the theory of Rousseau and Wielhorski and to conclude the main issue of both Rousseau's Polish debates. Unlike Rousseau, Wielhorski does not see any universal value in his own society, because he regards it just as an instrumental tool - for him it is necessary to save the Polish state that can serve the interests of Polish citizens and the only way to do it is to accept modern and appropriate Western patterns of human values. Hence, when Wielhorski wants to preserve Polish traditions, he cares about the political institutions and not the particular way of life, because there is no reason for Poles in being different from Western European citizens. This, of course, contradicts the vision of Rousseau who believes that keeping Polish communal virtues alive is necessary for the right progress of all humanity. When Rousseau in comparison with Wielhorski refuses to regard liberty as a strict individual value and calls for the necessity of collective agreement based on the concept of general will from Social Contract, it resembles his position he advocated before in the dispute against Leszczyński, because there he protested against individualist perspective as well. This crucial difference therefore reflects that where Leszczyński and Wielhorski perceived Eastern Europe as a space for urgent reforms coming from the West, Rousseau considered it as a true bulwark of liberty and hope for the future society.

Notes

1. This statement might sound questionably, but one should realize that even during the Cold War, when the antagonism between West and East in Europe probably culminated, the line of "Iron Curtain" was not fully indisputable, taking countries like Yugoslavia of Finland into account.

2. Carl Schmitt, The Concept of the Political. Expanded Edition (Chicago: University of Chicago Press, 2007), trans. G. Schwab, p. 26.

3. James W. Muller, Churchill's "Iron Curtain" Speech Fifty Years Later (Columbia and London: University of Missouri Press, 1999), p. 8.

4. Immanuel Wallerstein, The Modern World System I. Capitalist Agriculture and the Origins of the European World-Economy in the Sixteenth Century (London: University of California Press, 2011), p. 68.

5. Czesław Miłosz, The Witness of Poetry (Cambridge: Harvard University Press, 1982), p. 4.

6. Piotr S. Wandycz, Price of Freedom. A History of East Central Europe From the Middle Ages to the Present (London and New York: Routledge, 2005), p. 2.

7. Hans Lemberg, "Zur Enstehung des Osteuropabegriffs im 19. Jahrhundert. Vom Norden zum Osten Europas,” Jahrbücher für Geschichte Osteuropas 33 (1985).

8. Both quotations: Piotr S. Wandycz, op. cit., p. 4. 
9. For the detailed distinction of both these groups see e.g. Jerzy Lukowski, Liberty's Folly. The Polish-Lithuanian Commonwealth in the Eighteenth Century 1697-1795 (London and New York: Routledge, 2005); Jerzy Lukowski, Disorderly Liberty. The Political Culture of the Polish-Lithuanian Commonwealth in the Eighteenth Century (London: Continuum, 2012).

10. For the interpretation of political thought of the Bar Confederation members, see e.g. Arkadiusz Michał Stasiak, "Republican and Monarchical Patriotism in Polish Political Thought During the Enlightenment," in Whose Love of Which Country? Composite States, National Histories and Patriotic Discourses in Early Modern East Central Europe, eds. Balázs Trencsényi and Márton Zászkaliczky (Leiden and Boston: Brill, 2010), pp. 711-33.

11. Both quotations: Jean-Jacques Rousseau, The Government of Poland, trans. Willmoore Kendall (Indianapolis: Hackett Publishing Company, 1985), pp. 1-2.

12. There are serious doubts whether the king Stanisław Leszczyński wrote the responses to Rousseau or whether he used "ghost writer" services from some of his retinue which is highly probable in the case of his another work Glos wolny wolnośc ubezpieczajacy. However, the question of authorship is not relevant for the main aim of this study as Rousseau led the debate with the king accepting his assumed authorship. See Emanuel Rostworowski, "Czy Stanisław Leszczyński jest autorem Głosu wolnego?” in Legendy i fakty XVIII w., ed. Emanuel Rostworowski (Warszawa: PWN, 1963), pp. 125-44.

13. On the theory of mythologies see Quentin Skinner, "Meaning and Understanding in the History of Ideas," History and Theory 8.1 (1969), pp. 3-53.

14. Stanisław Leszczyński, “Odpowiedż króla polskiego na rozprawę Jana Jakuba Rousseau nagrodzoną przez Akademię w Dijon," in Marian Skrzypek, Filozofia i myśl społeczna w latach 1700-1830 (Warszawa: Wydawnictwo Instytutu Filozofii i Socjologii PAN, 2000), pp. 635-43.

15. Jean-Jacques Rousseau, "Observations by Jean-Jacques Rousseau of Geneva. On the Answer Made to His Discourse," in Jean-Jacques Rousseau, Rousseau. "The Discourses" and Other Early Political Writings. Cambridge Texts in the History of Political Thought, ed. Victor Gourevitch (Cambridge: Cambridge University Press, 1997), pp. 32-51.

16. Jean-Jacques Rousseau, "Observations by Jean-Jacques Rousseau of Geneva. On the Answer Made to His Discourse," in Rousseau. "The Discourses" and Other Early Political Writings, op. cit., p. 32; Jean-Jacques Rousseau, Confessions (London: Privately Published, 1903), p. 232.

17. Stanisław Leszczyński, "Odpowiedź króla polskiego," op. cit., p. 641.

18. Irena Stasiewicz-Jasiukowa, "Leszczyński contra Rousseau," Kwartalnik Historii Nauki i Techniki 23/1 (1978), p. 59.

19. Stanisław Leszczyński, "Odpowiedź króla polskiego,” op. cit., p. 640.

20. Stanisław Leszczyński, "Odpowiedź króla polskiego,” op. cit., p. 637.

21. Charles Taylor, "Cross-Purposes: The Liberal-Communitarian Debate," in Philosophical Arguments, ed. Charles Taylor (London: Harvard University Press, 1995), pp. 181-203.

22. Jean-Jacques Rousseau, "Observations by Jean-Jacques Rousseau of Geneva," op. cit., p. 45.

23. Jean-Jacques Rousseau, Rousseau. "The Discourses" and Other Early Political Writings, op. cit., p. 6.

24. Jean-Jacques Rousseau, Rousseau. "The Discourses" and Other Early Political Writings, op. cit., p. 33.

25. Jean-Jacques Rousseau, Rousseau. "The Discourses" and Other Early Political Writings, op. cit., p. 33.

26. Rousseau, J. J., "Observations by Jean-Jacques Rousseau of Geneva,” op. cit., p. 35.

27. Stanisław Leszczyński, “Odpowiedź króla polskiego,” op. cit., p. 639.

28. Stanisław Leszczyński, “Odpowiedź króla polskiego,” op. cit., p. 639.

29. Stanisław Leszczyński, "Odpowiedź króla polskiego,” op. cit., p. 638.

30. Marian Golka, "Stanisław Leszczyński jako polemista Jana Jakuba Rousseau," Dialogi o kulturze i edukacji 1 (2012), p. 66.

31. Stanisław Leszczyński, "Odpowiedź króla polskiego,” op. cit., p. 637.

32. Stanisław Leszczyński, "Odpowiedź króla polskiego," op. cit., p. 638.

33. Rousseau, J. J., "Observations by Jean-Jacques Rousseau of Geneva,” op. cit., p. 37.

34. Jean-Jacques Rousseau, The Government of Poland, op. cit., p. 1.

35. Jean-Jacques Rousseau, The Government of Poland, op. cit., p. 2.

36. Jean-Jacques Rousseau, The Government of Poland, op. cit., p. 1.

37. Rousseau stated the example of Moses who "founded the body of the nation from a swarm of wretched fugitives who possessed no skills, no arms, no talents, no virtues and no courage" and thus he managed to "transform servile emigrants into a political society and free people," Jean-Jacques Rousseau, The Government of Poland, op. cit., p. 6.

38. This interpretation made by Lukowski can be supported by Wielhorski quotations like: "zważmy nadto: iż większa jest jeszcze daleko część Obywatelów staropolską cnotę w sercach mających" or "dawne zwyczaje i przywiedzione prawa, jawnie w nich ujźrzeć można maksymy, którymi się powodowali przodkowie naszy i na których należy nam rząd nasz zasadzić, a w prawodawstwie wziąć oneż za prawidlo," Jerzy Lukowski, Disorderly Liberty, op. cit., p. 139; Michał Wielhorski, O przywróceniu dawnego rzqdu wedlug pierwiastkowych Rzeczypospolitey ustaw (Amsterdam, 1775), pp. 251, 118.

39. "Jeżeli dotąd tyle nie mamy samowładców, ile ministrów, winniśmy to jeszcze zabytkom wkorzenionego w serca

Polaków obywatelstwa," Michał Wielhorski, O przywróceniu dawnego rzqdu, op. cit., p. 128.

40. Both quotations: Michał Wielhorski, O przywróceniu dawnego rzadu, op. cit., p. 85.

41. Jean-Jacques Rousseau, The Government of Poland, op. cit., p. 59. 
42. "Azaliż każdy szlachcic z pierwszego wejrzenia nie widzi wszystkich stopniów godności i urzędów, które ma przebyć? Azaliż wszystko go nie przeświadcza, iż szczególnie cnota i przymioty przychylności i poważania całego Narodu zjednać mu mogą?" Michał Wielhorski, O przywróceniu dawnego rzqdu, op. cit., p. s. 319.

43. Michał Wielhorski, O przywróceniu dawnego rzqdu, op. cit., pp. 320-1.

44. "Łatwiej im było jednego uwieść albo przekupić posła dla przeszkodzenia użytecznemu Rzeczypospolitej postanowieniu, aniżeli większość głosów zjednać dla ustanowienia Prawa wolności Narodowej szkodliwego...," Michał Wielhorski, $O$ przywróceniu dawnego rzqdu, op. cit., s. 251.

45. Andrzej Walicki, Idea narodu w polskiej myśli oświeceniowej (Warszawa: Polska Akademia Nauk Instytut Filozofii i Socjologii, 2000), p. 31.

46. Jean-Jacques Rousseau, The Government of Poland, op. cit., p. 41.

47. Jean-Jacques Rousseau, The Government of Poland, op. cit., p. 10.

48. Jean-Jacques Rousseau, The Government of Poland, op. cit., p. 11.

49. Jean-Jacques Rousseau, The Government of Poland, op. cit., p. 11.

50. Benjamin Constant, "The Liberty of the Ancients Compared With That of the Moderns," in Constant. Political Writings. Cambridge Texts in the History of Political Thought, ed. Biancamaria Fontana (Cambridge: Cambridge University Press 1988), p. 309-28.

51. Jean-Jacques Rousseau, The Government of Poland, op. cit., p. 5.

52. Jean-Jacques Rousseau, The Government of Poland, op. cit., p. 11.

53. Jean-Jacques Rousseau, The Government of Poland, op. cit., p. 12.

54. Jean-Jacques Rousseau, The Government of Poland, op. cit., p. 14. 